\title{
In vitro Biofumigation of Brassica Tissues Against Potato Stem Rot Caused by Sclerotinia sclerotiorum
}

\author{
Mohammad Reza Ojaghian, Heng Jiang, Guan-Lin Xie*, Zhou-qi Cui, Jingze Zhang and Bin Li \\ State Key Laboratory of Rice Biology, Institute of Biotechnology, Zhejiang University, Hangzhou 310058, China \\ (Received on November 30, 2011; Revised on May 2, 2012; Accepted on May 14, 2012)
}

Sclerotinia sclerotiorum is a serious pathogen which causes yield loss in many dicotyledonous crops including potato. The objective of this study was to assess the potential of biofumigation using three Brassica crops including Brassica napus, B. juncea and $B$. campestris against potato stem rot caused by $S$. sclerotiorum by in vitro tests. Both macerated and irradiated dried tissues were able to reduce radial growth and sclerotia formation of five pathogen isolates on PDA, but macerated live tissues were more effective. Compared with other tested crops, B. juncea showed more inhibitory effect against the pathogen. The volatile compounds produced from macerated tissues were identified using a gas chromatograph-mass spectrometer. The main identified compounds were methyl, allyl and butyl isothiocyanates. Different concentrations of these compounds inhibited mycelial growth of the pathogen in vitro when applied as the vapor of pure chemicals. A negative relationship was observed between chemicals concentrations and growth inhibition percentage. In this study, it became clear that the tissues of local Brassica crops release glucosinolates and have a good potential to be used against the pathogen in field examinations.

Keywords : dual culture, glucosinolates, ion trap detector, volatile compounds

Potato white mold, also known as stem rot, is a damaging disease caused by the fungus Sclerotinia sclerotiorum. This disease usually occurs in a large number of potato fields in Hamadan, Iran (Ojaghian, 2009) resulting in reduced yield and tuber quality. Application of fungicides, mainly iprodione and dichloran, is the only control method being used by local growers and it has caused environmental concerns leading to find non-chemical control methods such as biofumigation.

It has been shown in numerous studies that the use of Brassica crops as green manure provides promising alter-

\footnotetext{
*Corresponding author.

Phone) 0086-13216102556, FAX) 0086-15238565789

E-mail)glxie@zju.edu.cn
}

natives to synthetic chemical fumigants (Brown and Morra, 1997). Brassica crops are considered as break crops because they are able to break the life cycle of several soil borne pathogens such as wheat take-all (Brennan and Murray, 1988). They have been proved to be effective against numerous nematodes (Buskov et al., 2002), fungal plant pathogens (Kirkegaard et al., 1996) and weeds (Boydston and Hang, 1995). These biocontrolling effects are attributed to the production of volatile biotoxic compounds through a process which is known as biofumigation. The cruciferous tissues possess thioglucoside compounds known as glucosinolates (GSLs), the secondary polar sulfur metabolites, which are the reason for the sharp or biting taste of condiments or the flavors of different edible Brassica tissues (McGregor et al., 1983). The GSLs are not harmful to organisms by themselves but they can change into isothiocyanates (ITCs), nitriles, thiocyanates, and oxazolidinethiones and other toxic compounds (Bending and Lincoln, 1999) by the endogenous enzyme myrosinase when Brassica tissues are damaged (Bones and Rossiter, 1996). The quality of the hydrolysis products depends on the type of organic side chain on the parent molecule and the environmental conditions (Rosa et al., 1997).

No research has been conducted on the presence and identification of GSLs in Iranian cultivars of Brassicas. The objective of this study was to evaluate the potential of biofumigation using three local Brassica crops against a number of $S$. sclerotiorum isolates by in vitro experiments.

Firstly, the inhibitory effects of Brassica tissues on radial growth and sclerotia formation of $S$. sclerotiorum were determined. Five highly aggressive isolates of $S$. sclerotiorum (Sc18d; Bahar, Sd6b; Bahar, Sd21n; Lalehjin, Sc59k; Bahar and $\mathrm{Sa} 21 \mathrm{~b}$; Lalehjin) were obtained from the Culture Collection of Plant Pathology Laboratory, Agriculture College, BuAli Sina University, Hamadan, Iran. These isolates had already been sampled in five heavily infected potato fields in Hamadan province. The isolates were routinely cultured on potato dextrose agar (PDA, $39 \mathrm{~g} / \mathrm{L}$; Merck, Darmstadt, Germany) and stored at $4 \pm 1^{\circ} \mathrm{C}$ for further use.

Canola (Brassica napus cv. Mettah), Indian mustard (Brassica juncea cv. Bresska) and Ida gold field mustard (Brassica campestris cv. Orrega) were grown in a glasshouse 
in $30 \mathrm{~cm}$ diameter pots containing sandy loam soil to facilitate recovery of roots. Plants tissues including root pieces and green above-ground tissues in equal amounts were collected at 10-leaf stage, and washed with tap water and dried out. A part of tissues was dried for one week and then irradiated (2.7 Mrad $\gamma$ ) to exclude contaminating organisms. Another part of the tissues was disinfected in ethanol $10 \%$ for $10 \mathrm{sec}$, rinsed in sterile distilled water (SDW) for $5 \mathrm{~min}$, dried on autoclaved filtering paper and macerated using a sterile mortar and pestle. In in vitro tests, $2 \mathrm{~g}$ of irradiated dried tissues of three Brassica crops was placed in Petri plates $(90$ $\mathrm{mm}$ ), and the lid of each plate was replaced with bottom of another PDA (39 g/l; Merck, Darmstadt, Germany) plate inoculated centrally with $5 \mathrm{~mm}$ mycelial discs taken from the edge of 4 days-old culture of five isolates of S. sclerotiorum. In other treatments, $2 \mathrm{~g}$ of fresh macerated tissues of three Brassica crops were placed in the lower plates. In all treatments, the pairs of each Petri dish were sealed together in sterile conditions with paraffin tape to prevent them from any infection and escape of volatile materials. Because volatile substances always move upwards, the tissue sections were always in the lower sections and the PDA containing section with the organism was inverted over the lower section. The pathogen, Brassica tissue and the controls were added to the plates at the same time and under sterile condition. The paired plates were incubated at $24 \pm 1^{\circ} \mathrm{C}$ for 5 days. The PDA used in this experiment had been amended with $150 \mathrm{ppm}$ streptomycin sulfate (Djaber Ibne Hayyan, Tehran, Iran). There were three sets of controls. No added material was in the first plates, and the second plates had $2 \mathrm{~g}$ of dried irradiated cortex of balsa as an example of plant material which was presumed to be inert. The third control plates were included a drop of SDW. This experiment was repeated three times in three consecutive weeks with five repetitions for each treatment, and the effects of different treatments were determined in a completely randomized design. The radial growth of $S$. sclerotiorum in all plates was calculated and percent inhibition of radial growth in each treatment was measured 5 days after inoculation by the formula $I=(C-T) / C$ $\times 100$, where $I=$ percent growth inhibition, $C=$ colony diameter of pathogen in control, and $T=$ colony diameter of pathogen in treatment. In addition, the percent inhibition of sclerotia formation was determined 15 days after inoculation using formula $\mathrm{N}_{\mathrm{T}} \times 100 / \mathrm{N}_{\mathrm{C}}$, where $\mathrm{N}_{\mathrm{T}}=$ number of sclerotia in treatment and $\mathrm{N}_{\mathrm{C}}=$ number of sclerotia in control.

In second step, gas chromatograph-mass spectrometry was carried out to assess the vapors produced from Brassica tissues. As explained above, canola, Indian mustard and Ida gold field mustard were grown from seed in a greenhouse and Brassica tissues were collected at the 10-leaf stage. $100 \mathrm{~g}$ of plant tissues including $50 \mathrm{~g}$ root pieces and $50 \mathrm{~g}$ aboveground tissues was washed with tap water, dried on filtering paper, and macerated with a mortar and pestle. In order to dissolve any volatile compounds released from the tissues, moist air was transferred over the macerated tissues and bubbled using a methanol trap at room temperature (25$27^{\circ} \mathrm{C}$ ). By means of mass spectrometry (Finnigan ${ }^{\mathrm{TM}} \mathrm{LTQ}^{\mathrm{TM}}$ ) on a ion trap detector and after they were separated on a 15meter silica capillary column (12QC/BP1.0.25, SGE Scientific) methyl, allyl and butyl ITCs were identified in the methanol solution for all three experimented crops. In this experiment, a split/splitless injector was used for injection of chemicals. The column was fixed at $45^{\circ} \mathrm{C}$ for $125 \mathrm{sec}$, and the temperature was increased to $195^{\circ} \mathrm{C}$ at $25^{\circ} \mathrm{C} / \mathrm{min}$. The mean retaining times of methyl, allyl and butyl ITCs for all crops were 245, 335 and $342 \mathrm{sec}$, respectively. The main ions of methyl, allyl and butyl ITCs were also observed in 71-58, 9875 and $120-59 \mathrm{~m} / \mathrm{z}$, respectively. These experiments replicated three times in three consecutive months. The following in vitro tests were conducted based on the identified ITCs in this experiment.

In next step, inhibitory effect of pure ITCs on growth of $S$. sclerotiorum was determined under in vitro condition. As explained above for the effects of Brassica tissues on growth of S. sclerotiorum, sealed pairs of Petri plates were provided but different concentrations of ITCs were placed in lower plates, instead of plant tissues. In order to prevent bacterial infection, the PDA used in this experiment was amended with 150 ppm streptomycin sulfate. Methyl, allyl and butyl ITC (J \& K SCIENTIFIC LTD, China) were dissolved in 1,4 dioxan (Merck, Darmstadt, Germany) and serially diluted to obtain $500 \mu \mathrm{l}$ ITC/1 Dioxan. The physical state of methyl isothiocyanate is solidified melt and its melting point is $35^{\circ} \mathrm{C}$, therefore it was softly heated in a test tube using a laboratory bain-marie to become liquid. Under sterile condition 1, 2, 3 and $4 \mathrm{~mL}$ of the solutions were placed in lower plates. Pure 1,4 dioxan in 1, 2, 3 and $4 \mathrm{~mL}$ was used in control plates. This in vitro experiment was repeated four times in four consecutive weeks with four repetitions for each treatment and controls. Inhibitory effect of different concentrations on linear growth of the pathogen was calculated 5 days after inoculation in laboratory conditions $24 \pm 1^{\circ} \mathrm{C}$ using the formula described for the effects of Brassica tissues on growth of S. sclerotiorum.

The means of treatments recorded in percent were transformed in $\mathrm{Sin}^{-1}$ percentage transformation (Gomez and Gomez, 1984). The effects of different treatments in each experiment were determined by the analysis of variance (ANOVA) using SAS software (SAS 8.2, 1999-2001; SAS Institute Inc., Cary, NC) in completely randomized design tests. Means of treatments were separated using Fishers' LSD test.

After 5 days of incubation, the results showed that the effect of volatile inhibitors produced from fresh macerated tissues against five isolates growth was significantly different from untreated controls (Table 1, Fig. 1). In addition, the number of sclerotia after 15 days was reduced in nearly all 
Table 1. Percentage of radial growth inhibition of S. sclerotiorum (five isolates) on PDA by the volatile compounds of three Brassica crops after 5 days at $24^{\circ} \mathrm{C}$

\begin{tabular}{|c|c|c|c|c|c|c|}
\hline & \multicolumn{6}{|c|}{ Radial growth inhibition $(\%)^{d}$} \\
\hline & \multicolumn{3}{|c|}{ Irradiated dried tissues } & \multicolumn{3}{|c|}{ Fresh macerated tissues } \\
\hline & B. campestris & B. juncea & B. napus & B. campestris & B. juncea & B. napus \\
\hline controls & $0^{\mathrm{a}}$ & $0^{\mathrm{a}}$ & $0^{\mathrm{a}}$ & $0^{\mathrm{a}}$ & $0^{\mathrm{a}}$ & $0^{\mathrm{a}}$ \\
\hline Sc18d & $15 \pm 6.1^{\mathrm{b}}$ & $30 \pm 9.7^{\mathrm{b}}$ & $15 \pm 4.4^{\mathrm{b}}$ & $65 \pm 21.4^{\mathrm{c}}$ & $87 \pm 18.9^{c}$ & $78 \pm 14.5^{\mathrm{c}}$ \\
\hline $\mathrm{Sd} 6 \mathrm{~b}$ & $0^{\mathrm{a}}$ & $34 \pm 11.2^{\mathrm{b}}$ & $16 \pm 7.6^{\mathrm{b}}$ & $52 \pm 11.2^{\mathrm{b}}$ & $74 \pm 12.7^{\mathrm{b}}$ & $62 \pm 6.1^{\mathrm{b}}$ \\
\hline $\mathrm{Sd} 21 \mathrm{n}$ & $15.5 \pm 4.4^{\mathrm{b}}$ & $32 \pm 12.8^{\mathrm{b}}$ & $15.6 \pm 5.6^{\mathrm{b}}$ & $62 \pm 12.3^{\mathrm{c}}$ & $89 \pm 12.5^{c}$ & $65 \pm 12.6^{\mathrm{b}}$ \\
\hline Sc59k & $14.5 \pm 3.7^{\mathrm{b}}$ & $45 \pm 9.4^{\mathrm{c}}$ & $15.5 \pm 3.5^{\mathrm{b}}$ & $63 \pm 11.8^{c}$ & $90 \pm 9.3^{c}$ & $80 \pm 27.8^{c}$ \\
\hline $\mathrm{Sa} 21 \mathrm{~b}$ & $15 \pm 3.8^{b}$ & $33 \pm 8.3^{b}$ & $0^{\mathrm{a}}$ & $63 \pm 24.1^{\mathrm{c}}$ & $76 \pm 10.2^{b}$ & $81 \pm 15.5^{\mathrm{c}}$ \\
\hline
\end{tabular}

${ }^{\mathrm{d}}$ Within columns, means followed by a common letter do not differ significantly at the $P<0.05$ level of confidence according to Fisher's test. Values in the table indicate means \pm standard error. This experiment was repeated three times and each treatment was replicated five times.

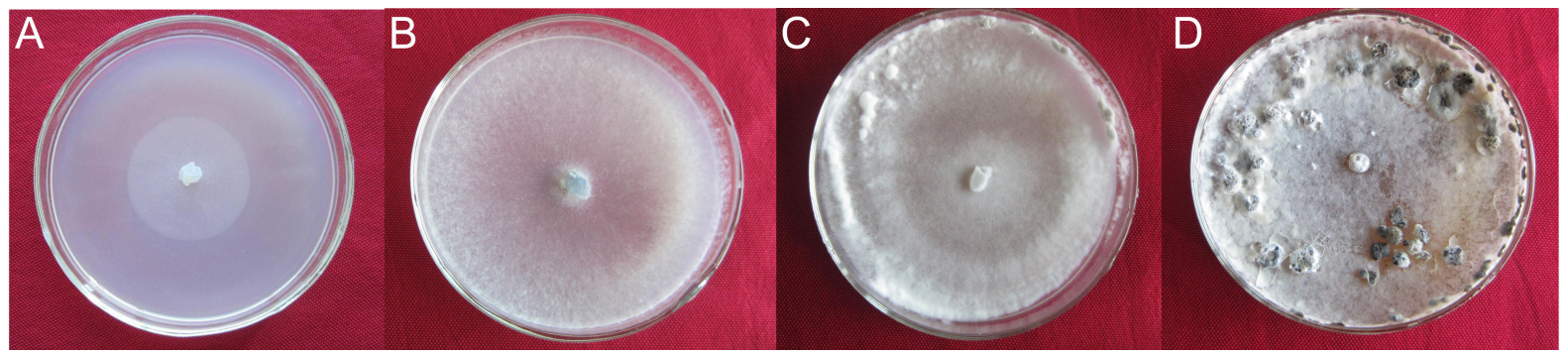

Fig. 1. Inhibitory effect of volatile materials released from fresh macerated tissues of Brassica juncea (placed in the lid of plates) against mycelial growth and sclerotia formation of S. sclerotiorum (isolate Sa21b). Compared with control (B, sterile distilled water), the radial growth of the pathogen (A) was meaningfully reduced after 5 days. In addition, the sclerotia formation (C) was significantly inhibited after 15 days comparing with the control (D).

isolates compared with controls (Table 2, Fig. 1). In B. napus, the least effect on radial growth was observed in Sd6b and $\mathrm{Sd} 21 n$ whereas other isolates showed statistically the most growth inhibition. The most inhibitory effect against sclerotia formation was observed in Sd6b and Sc59kb followed by other isolates with at par results (Tables 1 and 2). In B. campestris, the least growth inhibition was observed in $\mathrm{Sd} 6 \mathrm{~b}$ and other isolates showed statistically similar results. Furthermore, the least biocontrol effect against sclerotia formation was observed in $\mathrm{Sa} 21 \mathrm{~b}$ and $\mathrm{Sd} 21 \mathrm{n}$ whereas $\mathrm{Sd} 6 \mathrm{~b}$ was most effected isolate (Tables 1 and 2). Compared with other Brassica crops, $B$. juncea caused maximum inhibition growth and sclerotial formation of the pathogen isolates. The growth inhibition percentage was recorded as 87, 89 and 90 in Sc18d, $\mathrm{Sd} 21 \mathrm{n}$ and Sc59k, respectively. Significantly different from other isolates, Sd6b and $\mathrm{Sa} 21 \mathrm{~b}$ were similarly affected. Additionally, Indian mustard was able to reduce considerably the sclerotia formation in all isolates with statistically similar

Table 2. Inhibition percentage of sclerotia formation of S. sclerotiorum (five isolates) on PDA by the volatile compounds of three Brassica crops after 15 days at $24^{\circ} \mathrm{C}$

\begin{tabular}{|c|c|c|c|c|c|c|}
\hline & \multicolumn{6}{|c|}{ Percent inhibition of sclerotia formation ${ }^{\mathrm{e}}$} \\
\hline & \multicolumn{3}{|c|}{ Irradiated dried tissues } & \multicolumn{3}{|c|}{ Fresh macerated tissues } \\
\hline & B. campestris & B. juncea & B. napus & B. campestris & B. juncea & B. napus \\
\hline controls & $0^{\mathrm{a}}$ & $0^{\mathrm{a}}$ & $0^{\mathrm{a}}$ & $0^{\mathrm{a}}$ & $0^{\mathrm{a}}$ & $0^{\mathrm{a}}$ \\
\hline Sc18d & $45 \pm 2.5^{\mathrm{c}}$ & $62 \pm 8.1^{\mathrm{c}}$ & $40 \pm 8.4^{b}$ & $41 \pm 11.4^{\mathrm{c}}$ & $81 \pm 11.9^{\mathrm{b}}$ & $51 \pm 8.1^{\mathrm{b}}$ \\
\hline Sd6b & $25 \pm 5.9^{b}$ & $55 \pm 9.5^{b}$ & $53 \pm 5.6^{c}$ & $78 \pm 13.27^{\mathrm{d}}$ & $82 \pm 14.5^{b}$ & $78 \pm 5.6^{c}$ \\
\hline $\mathrm{Sd} 21 \mathrm{n}$ & $47 \pm 4.1^{\mathrm{c}}$ & $51 \pm 7.3^{\mathrm{b}}$ & $44 \pm 9.1^{\mathrm{bc}}$ & $28 \pm 3.7^{\mathrm{b}}$ & $79 \pm 9.3^{b}$ & $47 \pm 5.4^{\mathrm{b}}$ \\
\hline Sc59k & $23 \pm 5.1^{\mathrm{b}}$ & $49 \pm 9.4^{b}$ & $51 \pm 8.7^{\mathrm{c}}$ & $44 \pm 6.7^{\mathrm{c}}$ & $81 \pm 7.1^{\mathrm{b}}$ & $77 \pm 15.8^{\mathrm{c}}$ \\
\hline $\mathrm{Sa} 21 b$ & $28 \pm 4.7^{\mathrm{b}}$ & $63 \pm 4.2^{c}$ & $0^{\mathrm{a}}$ & $29 \pm 7.1^{\mathrm{b}}$ & $92 \pm 8.9^{\mathrm{bc}}$ & $50 \pm 16.1^{\mathrm{b}}$ \\
\hline
\end{tabular}

${ }^{\mathrm{e}}$ As same as noted for Table 1 . 
results (Tables 1 and 2 ).

The result of effects of volatile inhibitors produced from Irradiated dried tissues showed that all tested Brassica crops were significantly able to reduce radial growth and sclerotia formation of the most pathogen isolates, compared to untreated controls (Tables 1 and 2). In B. campestris, no inhibitory effect was observed in Sd6b and the other isolates showed statistically similar growth inhibition. The volatile materials inhibited sclerotia formation by 45 and $47 \%$ in $\mathrm{Sc} 18 \mathrm{~d}$ and $\mathrm{Sd} 21 \mathrm{n}$, respectively. The other three isolates were less affected and showed statistically similar results (Tables 1 and 2). In B. napus, no growth inhibition was found in $\mathrm{Sa} 21 \mathrm{~b}$ and the other isolates were inhibited with at par results. The most effect against sclerotia formation was observed in Sd6b and Sc59k. Canola was not able to show any inhibitory effect against sclerotia formation in Sa21b (Tables 1 and 2). Comparing to other Brassica crops, B. juncea showed the highest inhibitory effect on growth of the isolates and reduced the linear growth of Sc59k by $45 \%$, and other isolates were statistically similar inhibited. Furthermore, the most inhibition was observed in Indian mustard compared with other Brassica crops. The sclerotial formation was most inhibited in Sc18d and $\mathrm{Sa} 21 \mathrm{~b}$, and other isolates were less effected with statistically at par results (Tables 1 and 2).

In assessment of the pure ITCs against growth of S. sclerotiorum, the results revealed that all three tested isothio- cyanates significantly inhibited mycelial growth of the pathogen in four volumes after 5 days, compared with the untreated controls (Table 3). The reaction of isolates to different ITCs was not statistically similar. Methyl and allyl ITCs were more effective in reducing colony diameter compared with butyl ITC, and totally inhibited colony growth of all isolates in volumes 3 and $4 \mathrm{ml}$. In all tested ITCs, there was a positive association between increase of volumes and the rate of colony suppression. Contrary to methyl and allyl ITCs, no considerable inhibitory effect between volumes 1 and $2 \mathrm{ml}$ was observed (Table 3 ).

In this study, it became clear that tissues of canola, Indian mustard and Ida gold field mustard release glucosinolates which are able to inhibit the growth of S. sclerotiorum. Serving as inocula sources, sclerotia are principal surviving structures under adverse conditions (Adams, 1975). In addition to radial growth, inhibition of sclerotia information was considered in biocontrol evaluation of Brassica crops. As a new report, this study showed that volatile materials produced from Iranian cultivars of Brassica crops are significantly able to reduce sclerotial formation in S. sclerotiorum. Although inhibition of fungal growth by Brassica GSLs has been reported previously (Walker et al., 1937), no information was found about the biofumigation efficacy of local and common-cultivated cultivars in Iran, and before any field or greenhouse trials it was necessary to conduct in vitro tests

Table 3. Inhibitory effect (\%) of volatile compounds released from isothiocyanates solutions (500 $\mu 1$ isothiocyanate per 11 dioxan) at different volumes on radial growth of S. sclerotiorum (five isolates) on PDA after 5 days

\begin{tabular}{|c|c|c|c|c|c|}
\hline & & \multicolumn{4}{|c|}{ Radial growth inhibition (\%) } \\
\hline & & $1 \mathrm{ml}$ & $2 \mathrm{ml}$ & $3 \mathrm{ml}$ & $4 \mathrm{ml}$ \\
\hline \multirow{6}{*}{ Methyl isothiocyanate } & Control & $0^{c}$ & $0^{c}$ & $0^{c}$ & $0^{c}$ \\
\hline & Sc18d & $52 \pm 15.2^{\mathrm{a}}$ & $74 \pm 29.8^{\mathrm{a}}$ & $95 \pm 11.5^{\mathrm{a}}$ & $100 \pm 2.2^{\mathrm{a}}$ \\
\hline & Sd6b & $58 \pm 25.1^{\mathrm{ab}}$ & $73 \pm 35.2^{\mathrm{a}}$ & $94 \pm 10.5^{\mathrm{a}}$ & $100 \pm 3.5^{\mathrm{a}}$ \\
\hline & $\mathrm{Sd} 21 \mathrm{n}$ & $65 \pm 18.5^{\mathrm{b}}$ & $87 \pm 24.2^{b}$ & $97 \pm 9.9^{\mathrm{a}}$ & $100 \pm 5.8^{\mathrm{a}}$ \\
\hline & Sc59k & $67 \pm 23.1^{b}$ & $85 \pm 19.7^{b}$ & $94 \pm 15.9^{\mathrm{a}}$ & $98 \pm 12.2^{\mathrm{a}}$ \\
\hline & $\mathrm{Sa} 21 \mathrm{~b}$ & $52 \pm 14.9^{\mathrm{a}}$ & $75 \pm 17.5^{\mathrm{a}}$ & $95 \pm 14.6^{\mathrm{a}}$ & $97 \pm 9.5^{\mathrm{a}}$ \\
\hline \multirow{6}{*}{ Allyl isothiocyanate } & Control & $0^{c}$ & $0^{c}$ & $0^{c}$ & $0^{\mathrm{c}}$ \\
\hline & Sc18d & $58 \pm 11.8^{b}$ & $70 \pm 25.3^{\mathrm{a}}$ & $87 \pm 13.2^{\mathrm{a}}$ & $100 \pm 11.2^{\mathrm{a}}$ \\
\hline & Sd6b & $54 \pm 19.7^{b}$ & $71 \pm 16.3^{\mathrm{a}}$ & $90 \pm 29.5^{\mathrm{a}}$ & $99 \pm 15.5^{\mathrm{a}}$ \\
\hline & $\mathrm{Sd} 21 \mathrm{n}$ & $55 \pm 11.4^{\mathrm{b}}$ & $69 \pm 14.8^{\mathrm{a}}$ & $87 \pm 24.5^{\mathrm{a}}$ & $100 \pm 9.6^{\mathrm{a}}$ \\
\hline & Sc59k & $45 \pm 12.5^{\mathrm{a}}$ & $71 \pm 21.5^{\mathrm{a}}$ & $90 \pm 29.3^{\mathrm{a}}$ & $98 \pm 8.8^{\mathrm{a}}$ \\
\hline & $\mathrm{Sa} 21 \mathrm{~b}$ & $43 \pm 9.6^{\mathrm{a}}$ & $69 \pm 23.6^{\mathrm{a}}$ & $88 \pm 11.4^{\mathrm{a}}$ & $97 \pm 12.3^{\mathrm{a}}$ \\
\hline \multirow{6}{*}{ Butyl isothiocyanate } & Control & $0^{c}$ & $0^{c}$ & $0^{c}$ & $0^{c}$ \\
\hline & Sc18d & $45 \pm 6.2^{\mathrm{b}}$ & $48 \pm 10.2^{b}$ & $82 \pm 14.9^{b}$ & $84 \pm 8.6^{\mathrm{b}}$ \\
\hline & Sd6b & $28 \pm 5.5^{\mathrm{a}}$ & $35 \pm 8.9^{\mathrm{a}}$ & $65 \pm 19.8^{a}$ & $83 \pm 5.2^{\mathrm{b}}$ \\
\hline & $\mathrm{Sd} 21 \mathrm{n}$ & $47 \pm 11.3^{b}$ & $49 \pm 4.9^{b}$ & $84 \pm 19.5^{b}$ & $85 \pm 4.8^{b}$ \\
\hline & Sc59k & $25 \pm 5.5^{\mathrm{a}}$ & $32 \pm 8.5^{\mathrm{a}}$ & $65 \pm 9.3^{\mathrm{a}}$ & $81 \pm 10.8^{b}$ \\
\hline & $\mathrm{Sa} 21 \mathrm{~b}$ & $27 \pm 10.6^{\mathrm{a}}$ & $35 \pm 8.2^{\mathrm{a}}$ & $67 \pm 14.2^{\mathrm{a}}$ & $69 \pm 11.5^{\mathrm{ab}}$ \\
\hline
\end{tabular}

${ }^{\mathrm{d}}$ This experiment was repeated four times and each treatment was replicated four times. Within columns, means followed by a common letter do not differ significantly at the $P<0.05$ level of confidence according to Fisher's test. Values in the table indicate means \pm standard error. 
to prove the presence and efficiency of GSLs in Brassica tissues. Based on Table 1, Indian mustard tissues were more effective than canola and Ida gold field mustard tissues. These observations are compatible with previous researches which have shown that $B$. juncea contains higher levels of glucosinolates than most other Brassica species and also produces some of high antimicrobial forms of isothiocyanates (Charron and Sams, 1999; Smolinska and Horbowicz, 1999). In addition, Indian mustard tissues showed more inhibitory effect against sclerotia formation compared to other Brassica crops. Linear growth and sclerotia formation of the isolate $\mathrm{Sa} 21 \mathrm{~b}$ were not affected by volatile material produced by B. napus. It is quite known that different isolates of $S$. sclerotiorum varies in reaction to biocontrol agents and environmental conditions (Wu and Subbarao, 2008). Results of Table 3 showed that ITCs are the reason of radial growth inhibition. The volatile compounds released from macerated live tissues showed considerably more inhibitory effect than dead tissues. In addition, radial growth of the pathogen was reduced symmetrically, and it shows that tissues produce volatile metabolites. The results of this study suggested that the tissues of tested Brassica crops can be used for biofumigation, and should be considered as a helpful control measure against potato stem rot in Hamadan fields. It has been reported, on the other hand, that other factors may increase or decrease the activity of myrosinase, and reduction of plant diseases is not always associated with higher GSLproducing crops (Larkin and Griffin, 2007). For example, ascorbic acid (Kleinwachter and Selmar, 2004; Li and Kushad, 2005) and phenols (George et al., 2009) have been found to increase myrosinase activity affecting the amount of ITCs. Consequently it is not possible to predict the biofumigation potential of Brassica crops exactly based on GSLs concentration in their tissues. Moreover, myrosinase activity is also influenced by extrinsic factors such as cultivation in different conditions (Van-Eylen et al., 2008); therefore in order to evaluate the biofumigation efficacy of Brassica crops against potato stem rot, a number of field tests are being conducted in different regions of Hamadan province and in different cultural conditions.

\section{Acknowledgements}

This project was supported by the Special Fund for Agroscientific Research in the Public Interest (201003029, 201003066). The authors wish to acknowledge their gratitude to Abdulwareth Almoneafy, Wen-Xiao Tian, Guo-Qing Zhang, Yu Shi and He Liu.

\section{References}

Adams, P. B. 1975. Factors affecting survival of Sclerotinia scle- rotiorum in soil. Plant Dis. Rep. 59:599-603.

Bending, G. D. and Lincoln, S. D. 1999. Characterization of volatile sulphur-containing compounds produced during decomposition of Brassica juncea tissues in soil. Soil Biol. Biochem. 31:695-703.

Boydston, R. A. and Hang, H. A. 1995. Rapeseed (Brassica napus) green manure crop suppresses weeds in potato (Solanum tuberosum). Weed Technol. 9:669-675.

Brennan, J. P. and Murray, G. M. 1988. Australian wheat diseases: Assessing their economic importance. Agr. Sci. 127:26-35.

Brown, P. D. and Morra, M. J. 1997. Control of soil-borne plant pests using glucosinolate containing plants. Adv. Agron. 61: 167-231.

Bones, A. and Rossiter, J. T. 1996. The myrosinase-glucosinolate system, its organization and biochemistry. Physiol. Plantarum 97:194-208.

Buskov, S., Serra, B., Rosa, E., Sorense, H. and Sorensen, J. C. 2002. Effects of intact glucosinolates and products produced from glucosinolates in myrosinase-catalyzed hydrolysis on the potato cyst nematode (Globodera rostichiensis). J. Agric. Food Chem. 50:690-695.

Charron, C. S. and Sams, C. E. 1999. Inhibition of Pythium ultimum and Rhizoctonia solani by shredded leaves of Brassica species. J. Am. Soc. Hort. Sci. 124:462-467.

George, F., Bomford, M. and Vincelli, P. 2009. Screening Brassica species for glucosinolate content. J. Environ. Sci. Health: $311-$ 316.

Gomez, K. A. and Gomez, A. A. 1984. Statistical Procedures for Agricultural Research, John Wiley and Sons, pp. 139-153. Singapore.

Kirkegaard, J. A., Wong, P. T. W. and Desmarchelier, J. M. 1996. In vitro suppression of fungal root pathogens of cereals by Brassica tissues. Plant Pathol. 45:593-603.

Kleinwachter, M. and Selmar, D. 2004. A novel approach for reliable activity determination of ascorbic acid depending myrosinases. J. Biochem. Biophys. Meth. 59:253-265.

Larkin, R. P. and Griffin, T. S. 2007. Control of soilborne potato diseases using Brassica green manure. Crop Prot. 26:10671077.

Li, X. and Kushad, M. M. 2005. Purification and characterization of myrosinase from horseradish Armoracia rusticana roots. Plant Physiol. Biochem. 43:503-511.

McGregor, D. I., Mullin, W. J. and Fenwick, G. R. 1983. Analytical methodology for determining glucosinolate composition and content. J. Assoc. Anal. Chem. 66:825-849.

Ojaghian, M. R. 2009. First report of Sclerotinia sclerotiorum on potato plants in Iran. Australas. Plant Dis. Notes 41:39-41.

Purdy, L. H. 1979. Sclerotinia sclerotiorum: history, diseases and symptomatology, host range, geographic distribution and impact. Phytopathology 69:875-880.

Rosa, E. A. S., Heaney, R. K. and Fenwick, G. R. 1997. Glucosinolates in crop plants. Hort. Rev. 19:99-215.

Smolinska, U. and Horbowicz, M. 1999. Fungicidal activity of volatiles from selected cruciferous plants against resting propagules of soil-borne fungal pathogens. J. Phytopathol. 147: 119-124. 
Van-Eylen, D., Oey, I., Hendrick, M. and Van-Loey, A. 2008. Behavior of mustard seed Sinapis alba L. myrosinase during temperature. Eur. Food Res. Technol. 226:545-553.

Walker, J. C., Morell, S. and Foster, H. H. 1937. Toxicity of mustard oils and related sulfur compounds to certain fungi. Am. $J$.
Bot. 24:536-541.

Wu, B. M. and Subbarao, K. V. 2008. Effects of soil temperature, moisture, and burial depths on carpogenic germination of Sclerotinia sclerotiorum and S. minor. Phytopathology 98:1144-1152. 